\title{
Early influences on cardiovascular and renal development
}

\author{
J. J. Miranda Geelhoed · Vincent W. V. Jaddoe
}

Received: 9 May 2010/Accepted: 9 September 2010/Published online: 25 September 2010

(C) The Author(s) 2010. This article is published with open access at Springerlink.com

\begin{abstract}
The hypothesis that a developmental component plays a role in subsequent disease initially arose from epidemiological studies relating birth size to both risk factors for cardiovascular disease and actual cardiovascular disease prevalence in later life. The findings that small size at birth is associated with an increased risk of cardiovascular disease have led to concerns about the effect size and the causality of the associations. However, recent studies have overcome most methodological flaws and suggested small effect sizes for these associations for the individual, but an potential important effect size on a population level. Various mechanisms underlying these associations have been hypothesized, including fetal undernutrition, genetic susceptibility and postnatal accelerated growth. The specific adverse exposures in fetal and early postnatal life leading to cardiovascular disease in adult life are not yet fully understood. Current studies suggest that both environmental and genetic factors in various periods of life may underlie the complex associations of fetal growth retardation and low birth weight with cardiovascular disease in later life. To estimate the population effect size and to identify the underlying mechanisms, well-designed epidemiological studies are needed. This review is focused on
\end{abstract}

J. J. M. Geelhoed ( $₫)$ · V. W. V. Jaddoe

The Generation R Study Group, Erasmus Medical Center, PO Box 2040, 3000 CA Rotterdam, The Netherlands e-mail: j.geelhoed@erasmusmc.nl

J. J. M. Geelhoed · V. W. V. Jaddoe

Department of Epidemiology, Erasmus Medical Center, Rotterdam, The Netherlands

J. J. M. Geelhoed · V. W. V. Jaddoe

Department of Pediatrics, Erasmus Medical Center,

Rotterdam, The Netherlands specific adverse fetal exposures, cardiovascular adaptations and perspectives for new studies.

Keywords Fetal growth - Birth weight - Cardiovascular disease $\cdot$ Fetal origins $\cdot$ Epidemiology $\cdot$ Follow-up

\section{Introduction}

Many epidemiological studies from different geographical regions demonstrated consistent association between low birth weight and the risk of cardiovascular disease [1-3]. These associations can not be explained by preterm birth [4, 5]. Also, they seem to be independent of influences in adult life including social class, obesity and smoking habits $[6,7]$. The mechanisms underlying these associations are not well known. It has been suggested that developmental adaptations due to suboptimal fetal nutrition permanently program the fetus and lead to an increased risk of coronary heart disease many decades later [8]. It has also been argued that the associations between size at birth and later disease could primarily be the result from common genetic influences. Based on more recent studies, a more general developmental plasticity hypothesis has been proposed [9]. Developmental plasticity is defined as the ability of an organism to develop in various ways, depending on the particular environment or setting [10]. In this process, early environmental influences induces anatomical, physiological and biochemical adaptations in later life. These adaptations may be beneficial for short term survival but could have adverse long term consequences. This latter conceptual basis is extended with the Predictive Adaptive Response (PAR) theory, stating that long-term consequences of these early environmental influences may be especially harmful if the actual postnatal, mature, environment differs from the environment predicted 
during the plastic, developmental, phase [11]. The greater the degree of mismatch, the greater the disturbance in physiology and the greater the risk of disease.

Studies in humans generally use birth weight as measure of adverse fetal exposure. Birth weight might indeed be an indicator of the quality of the intra-uterine environment [12]. However, the same birth weight might be the result of different growth patterns and exposures in fetal life. Furthermore, a period of compensatory growth will follow after nutritional deficit in utero. The most rapid growth acceleration in low birth weight children occurs in the first weeks after birth [13]. This accelerated growth rate might also have important consequences later in life [14]. These findings suggest that children with both restricted fetal and infant growth and accelerated childhood weight gain are at particular risk of cardiovascular disease in adult life and its risk factors $[15,16]$.

In this paper, we discuss epidemiological studies designed to identify mechanisms underlying the associations of fetal growth retardation and low birth weight with the development of cardiovascular disease in adulthood. We will focus on specific adverse fetal exposures, cardiovascular adaptations and perspectives for new studies.

\section{Specific fetal exposures}

Fetal undernutrition

\section{Maternal anthropometrics, maternal diet and placenta function}

The fetal nutrition supply line includes maternal anthropometrics, diet and placenta function. Maternal anthropometrics during pregnancy are related to their nutritional and health status $[17,18]$. Several studies have shown that maternal anthropometric factors such as prepregnancy body mass index and weight gain during pregnancy are associated with fetal growth characteristics and adverse pregnancy outcomes [19-21]. Thus, the maternal nutritional and health status during pregnancy may lead to an adverse fetal environment and might affect fetal growth and development (Table 1).

Studies examining the direct effect of maternal anthropometrics on cardiovascular outcomes in the offspring demonstrated conflicting results (Table 1). Most of these studies were based on retrospective cohorts. We found in a prospective cohort study that maternal weight gain during pregnancy is associated with larger left ventricular mass at the age of 6 months, independent of maternal weight just before pregnancy [22]. Additionally, a recent study showed that greater maternal gestational weight gain is associated with greater offspring body mass index into early adulthood
Table 1 Maternal anthropometrics and diet in association with cardiovascular disease later in life

\begin{tabular}{ll}
\hline $\begin{array}{l}\text { Maternal anthropometric } \\
\text { characteristic during } \\
\text { pregnancy }\end{array}$ & Cardiovascular outcome \\
\hline $\begin{array}{l}\text { Maternal anthropometric } \\
\text { Short stature }\end{array}$ & $\begin{array}{c}\text { Increased death rates from } \\
\text { coronary heart disease }\end{array}$ \\
$\begin{array}{l}\text { Low triceps skin fold thickness } \\
\text { Increased blood pressure }\end{array}$ \\
$\begin{array}{l}\text { High weight gain during } \\
\text { pregnancy }\end{array}$ & $\begin{array}{l}\text { Increased left ventricular mass } \\
\text { Total energy intake }\end{array}$ \\
$\begin{array}{l}\text { Low protein intake } \\
\text { Low calcium intake }\end{array}$ & $\begin{array}{c}\text { Increased risk and earlier } \\
\text { onset coronary artery disease }\end{array}$ \\
Low folate intake & $\begin{array}{l}\text { Increased blood pressure } \\
\text { Increased blood pressure }\end{array}$ \\
\hline
\end{tabular}

and that this may translate into higher systolic blood pressure in the offspring [23]. Several underlying biological pathways may explain the associations between maternal anthropometrics during pregnancy and vascular development and cardiac growth and development postnatally. One explanation could be that the usual increase in insulin resistance seen in late pregnancy is higher in mothers who show a marked increase in weight during pregnancy, resulting in increased fetal body and cardiac growth [24, 25]. Further studies, in which measures of insulin resistance such as insulin, glucose or HbAlc levels in pregnancy have been measured, are needed to identify the potential role of insulin resistance for fetal cardiovascular development. The major limitation of weight gain is that the total amount depends on both an increase in fluid and fat mass. Also, it is not clear whether maternal pre-pregnancy weight or weight gain during pregnancy affects cardiovascular development in the offspring.

The fetal nutrition supply line may also be directly affected by dietary intake of the mother during pregnancy. Follow-up of persons who were conceived during the Dutch famine during the second World War demonstrated a doubled risk and an earlier onset of coronary artery disease among subjects who were exposed to famine during fetal life [16]. These results were independent of size at birth and current smoking and social economic status and suggest that severe maternal malnutrition during early gestation contributes to the occurrence of coronary artery disease in the offspring. However, these results could not be replicated in a cohort of adults who were exposed as fetus to severe famine during the siege of Leningrad [26]. The associations of less extreme variations in maternal intake of macronutrients and micronutrients with the 
development of risk factors for cardiovascular disease in the offspring have also been studied. Prospective cohort studies showed that variation in maternal total protein intake during pregnancy does not program offspring blood pressure already in infancy or in adolescence [27-29].

Stronger relations have been reported between micronutrients and risk factors for cardiovascular disease in the offspring. Maternal calcium supplementation during pregnancy has been described to be associated with lower systolic blood pressure in the offspring [30-32]. Although, in some follow-up studies the effect disappeared later in childhood and no association were reported in twins [33, 34]. Therefore, it is still unclear whether ensuring adequate calcium intake among pregnant women could be a way to prevent hypertension in the next generation. Low folate and high homocystein levels, in combination or independently, have been shown to be risk factors for endothelial dysfunction and cardiovascular disease [35, 36]. In healthy infants, a relationship between maternal folate levels during pregnancy and vascular endothelial function was demonstrated [37]. More recently developed statistical approaches, such as dietary patterns of maternal nutrition intake during pregnancy, may give more detailed inside in the development of risk factors for cardiovascular disease later in life.

Placental function, including placental weight and haemodynamic function is one of the most important determinants of the fetal supply line. Size of the placenta reflects only an indirect measure of its capacity to transfer nutrients to the fetus, but it is strongly associated with fetal size at birth [38]. A review focused on the associations of placental weight with the risk of cardiovascular disease in the offspring and reported no consistent associations [39]. Preeclampsia is considered as the most extreme form of haemodynamic placental dysfunction. According to recent studies, women with prior preeclamptic pregnancies are at increased risk of cardiovascular disease [40, 41]. Furthermore, preeclampsia has been associated with elevated blood pressure in offspring during childhood and adolescence [42]. Fetal growth restriction due to placental dysfunction or common genetic variants may at least partly explain these associations. A milder form of placental haemodynamic dysfunction is reflected by the resistance in the umbilical artery. An increased umbilical artery resistance is associated with fetal growth restriction and low birth weight [43].

\section{Maternal smoking during pregnancy}

Maternal smoking during pregnancy is strongly associated with fetal growth retardation [44-46]. The effects of smoking on placental vessels could be due to nicotine or hypoxia. This association is partly mediated by restricted blood flow in the vascular beds of the placenta, due to increased resistance of the umbilical-placental circulation [47, 48]. Fetal exposure to maternal smoking might also have adverse and persistent consequences for cardiovascular growth and development. Recent studies showed associations between intra-uterine exposure to maternal smoking and high blood pressure in childhood and adulthood [49, 50]. However, the association of maternal smoking and offspring blood pressure might be confounded by a comprehensive range of indicators of social economic position. Confounding by social and familial factors is further supported by the similarity of maternal and paternal smoking effects, suggesting that modest differences in childhood blood pressure associated with maternal smoking could be the result of not only biological effects on the intrauterine environment, but also common adverse familial factors [51]. Studies focused on fetal cardiovascular development may unravel these associations. We found in a prospective cohort study that maternal smoking during pregnancy is associated with placental and fetal haemodynamic adaptations indicating increased arterial resistance [52]. These fetal haemodynamic adaptations were subsequently associated with fetal growth retardation and changes in postnatal cardiac structures. Similarly, maternal smoking in pregnancy has also been suggested to be directly associated with changes in fetal cardiac dimensions and volumes [53, 54].

\section{Genetic susceptibility}

The association of fetal growth restriction and low birth weight with the increased risk of cardiovascular disease may also be explained by common genetic variants related to insulin sensitivity or angiogenesis (Table 2) [55]. Insulin and insulin-like growth factors are important fetal growth factors [56]. Genetic factors related to insulin or insulinlike growth factors production and sensitivity may lead to both impaired fetal growth and to type 2 diabetes and cardiovascular disease in later life [55]. Previously, Single Nucleotide Polymorphisms (SNPs) in the IGF1 gene and the INS VNTR gene have been suggested to be associated with fetal and postnatal growth. However, these effects seem not to be consistent $[57,58]$.

Common polymorphisms of type 2 diabetes gene $P P A R \gamma 2$ may also explain previously suggested associations of growth in early life with the risk of cardiovascular disease in later life. Two large birth cohort studies found no association between the $P P A R \gamma 2$ polymorphism and birth weight [59, 60]. We recently showed that the PPAR 2 Ala12 allele is associated with an increased growth rate in early life. This effect was modified by the duration of breastfeeding [61]. In addition to the PPAR 2 polymorphism, other common type 2 diabetes genetic susceptibility 

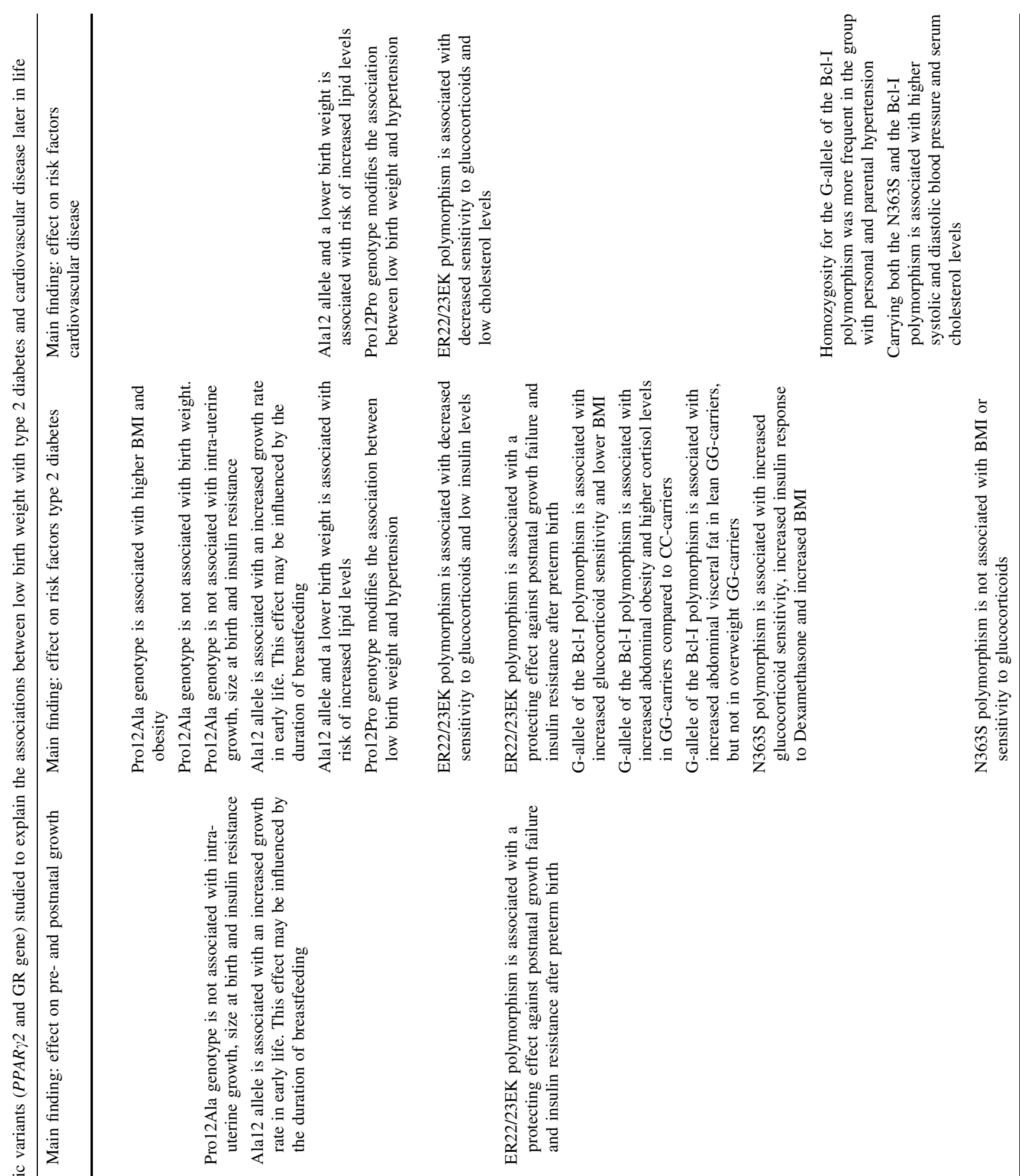

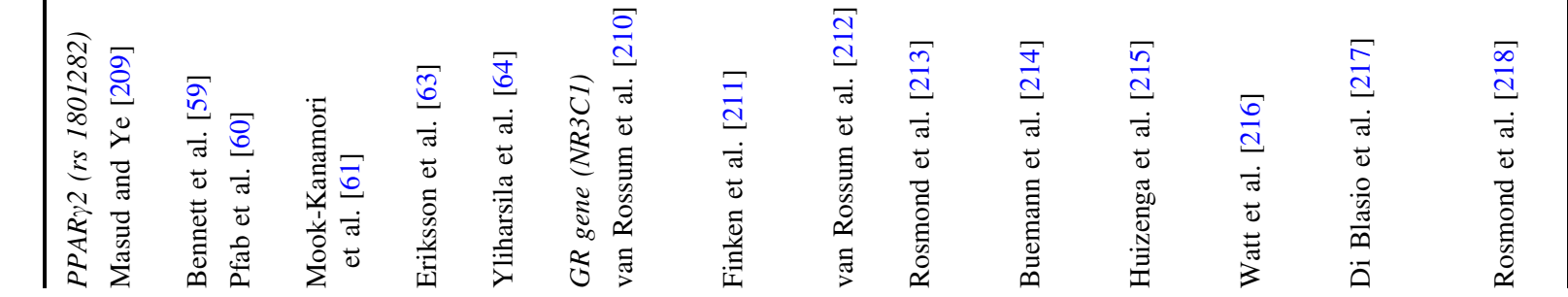




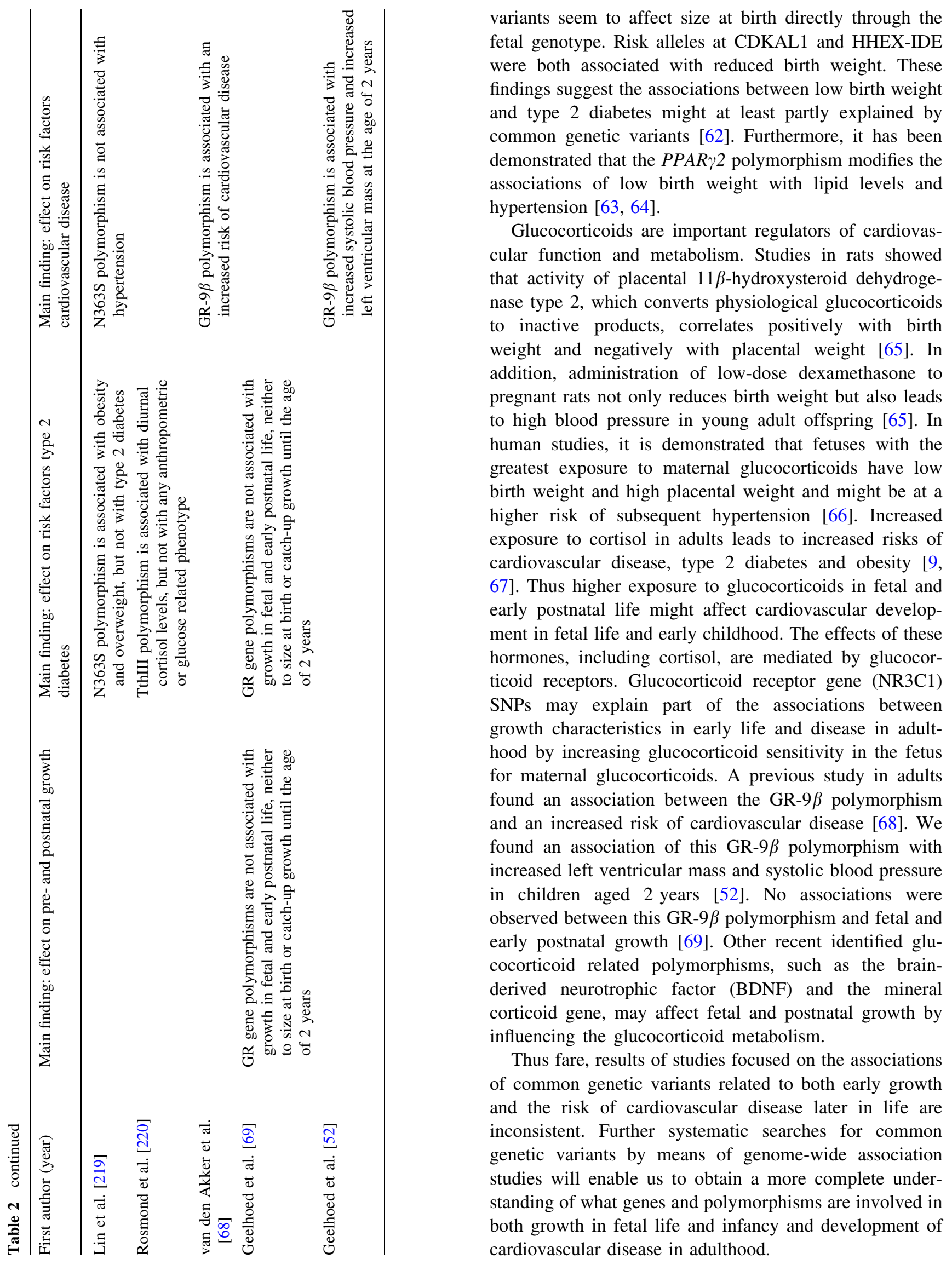




\section{Cardiovascular adaptations}

Cardiac development

Stimuli for cardiac development

It has been demonstrated that fetuses have stiffer fetal ventricles than neonates and the diastolic filling patterns in normally grown fetuses mimic those of the diseased adult heart [70]. Left ventricular elastic compliance increases with gestational age and left ventricular stiffness significantly decreases. In growth restricted fetuses, this process may be affected [70]. Furthermore, reduced end-diastolic flow velocities in fetal umbilical and maternal uteroplacental arteries have been associated with increased peripheral vascular resistance [71]. This increase in peripheral arterial resistance and subsequently in fetal cardiac afterload may lead to an increase in fetal cardiac performance and to persistent structural left ventricular changes [72]. Decreased fetal growth was also associated with fetal adaptations in cardiac function in the whole range of fetal growth [73]. Furthermore, birth weight and measures of placental vascular resistance and fetal cardiac output were associated with left cardiac structures until the age of 2 years [74]. This is in line with a previous prospective cohort study in children which demonstrated positive associations of birth weight with total coronary artery diameter, aortic root diameter and left ventricular outflow tract diameter in children aged 9 years [75]. However, inverse associations between birth weight and left ventricular mass in adolescents and adults have been demonstrated [76, 77]. It should be investigated whether these relations persist during later life and are related to the development of cardiovascular disease in adulthood.

\section{Adverse cardiac adaptations}

Studies in children showed that left ventricular mass tracks from childhood to adulthood [78, 79]. This implies that children with smaller left cardiac structures in early postnatal life tend to keep their relatively smaller left cardiac structures in childhood $[74,78,79]$. However, a relatively smaller left ventricle and aortic root may lead to insufficient cardiac functioning for increasing metabolic demands in postnatal life. Subsequently, the heart may respond by growth and adverse remodeling. Since the number of heart cells is established largely in fetal life, adaptation and growth of existing cells may eventually lead to left ventricular dysfunction and hypertrophy. Left ventricular hypertrophy is a strong and independent risk factor of cardiovascular morbidity and mortality in adulthood [80, 81]. Thus fetal exposures affecting cardiac development may have life long consequences.
Renal development

\section{Stimuli for renal development}

Nephrons start to form from day 30 of gestation [82]. Numerous factors, including the renin-angiotensin system (RAS), various growth factors, apoptosis and an adequate supply of nutrients are required for nephrogenesis [83-85]. Nephrogenesis continues until 36 weeks of gestation and the induction of nephron number ceases thereafter [86, 87]. On average $\pm 750,000$ nephrons per kidney are present, with a wide interindividual range $(250,000-2,000,000)$ [87-90].

Animal studies have shown that various determinants of fetal nutrition including low protein intake, relative vitamin A deficiency, reduced placenta perfusion and administration of steroids in late pregnancy cause fetal growth restriction, smaller kidneys and a permanent reduced nephron number [91-94]. Human studies demonstrated that low birth weight infants have lower kidney weight with a reduced number of nephrons [95, 96]. It was also demonstrated that hypertensive subjects have lower nephron numbers [90]. The best surrogate measure for assessing nephron number in epidemiological studies appears to be kidney weight or size measured by ultrasound [87]. A few studies investigated renal length or volume in early life. Being small for gestational age (SGA) is associated with small kidneys at birth and impaired kidney growth in early childhood [97]. Kidney length in preterm SGA infants follows closely the other anthropometric parameters during the first year of life [98]. SGA term infants had shorter kidney length at birth compared to appropriate for gestational age infants, but a similar length from 3rd to 24th month of life [99]. This may represent either an accelerated renal maturation or early compensatory kidney hypertrophy in the SGA infants. Maternal anthropometrics, fetal abdominal circumference, fetal blood flow redistribution, and raised placental resistance are associated with both third trimester fetal kidney volume and kidney volume at the age of 2 years $[100,101]$. Since, kidney size tracks from third trimester of pregnancy to early childhood, these adaptations may have persistent consequences [100].

\section{Adverse renal adaptations}

The kidneys respond to this reduced number of nephrons by hyperperfusion and remodelling [102]. According to the hyperfiltration theory, this will lead to more sodium reabsorption, increased systolic blood pressure and albuminuria [103]. This process may be in favor of short-term renal function but may eventually lead to glomerular hypertrophy and damage [102]. Finally, this may predispose the individual to renal failure and hypertension. It has been 
shown that low birth weight is associated with early onset chronic renal failure. In subjects aged less than 50 years, those who weighted less than $2.5 \mathrm{~kg}$ at birth had a higher risk for end-stage renal disease than people who weighted $3-3.5 \mathrm{~kg}$ at birth [104]. This association was shown in all groups of primary causes of end stage renal failure in adults (hypertension, diabetes and other causes). Studies in younger subjects have focused on urine albumin excretion, a predictor of cardiovascular and renal disease in diabetic and non-diabetic subjects [105]. Low birth weight is associated with microalbuminuria in children and adults independent of blood pressure and measures of insulin resistance [106, 107]. The pathway leading from small kidneys to hypertension may include the renin-angiotensin system, which has been demonstrated to be altered in the early phase of primary hypertension [108]. An increased activity of the renin-angiotensin system could be a compensatory mechanism in a decreased number of nephrons in order to maintain normal renal filtration. It has been demonstrated that renin activity in umbilical cord blood is inversely related with the size of the kidney at birth [109].

\section{Vascular development}

\section{Haemodynamic stimuli for fetal vascular development}

Fetal growth retardation leads to a preferential blood flow to the brain and heart, which deprives other organs of adequate oxygen and nutrients supply. This brain-sparing suggests organ specific vasodilatation and vasoconstriction and has been demonstrated in growth restricted fetuses [110]. In addition, we recently demonstrated that decreased fetal growth is associated with adaptive fetal cardiovascular changes [73]. These changes already occured before the onset of clinically apparent fetal growth restriction. Future studies are needed to identify whether these adaptations in fetal haemodynamics have consequences for the development of cardiovascular disease in later life.

\section{Endothelial function}

The endothelium controls vascular tone, coagulation and inflammatory responses [111]. Endothelial dysfunction is an early event of atherosclerosis, preceding structural changes in the vascular wall [112]. Atherosclerosis is thought to begin in childhood and to develop silently before clinical events such as myocardial infarction or stroke occur. Many studies demonstrated atherosclerotic wall thickening in the arteries of children with cardiovascular risk factors using ultrasound imaging [113]. Furthermore, studies have shown that risk factors for cardiovascular disease measured in childhood are track into adulthood $[114,115]$. There is limited direct evidence that risk factors measured in childhood are predictive of atherosclerosis in adulthood [116, 117]. Only a few studies examined the associations of fetal and maternal factors during pregnancy and vascular changes in childhood. Low maternal folate levels during pregnancy and low birth weight are demonstrated to be associated with vascular endothelial dysfunction in newborn infants [37, 118, 119]. Further follow up studies are needed.

\section{Arterial stiffness}

Flow may determine vascular growth in the fetal cardiovascular system and thereby a reduction in flow may alter later vascular behaviour [120]. One mechanism that could underlie the association of low birth weight with raised blood pressure may be a suboptimal development of the fetal cardiovascular system due to these circulatory changes, thus increasing the stiffness of the vessel wall and comprising the cardiovascular function [121]. Several studies have attempted to test this hypothesis by investigating the relationship between birth weight and indicators of arterial stiffness such as pulse wave velocity and pulse pressure, but with conflicting results [122-125]. Another mechanism could be that these haemodynamic adaptive changes in the fetal circulation, which occur in a critical period of blood vessel development, may influence rates of elastin synthesis [125]. This may result in a reduced compliance of the large arteries, leading to higher pulse and mean blood pressures. Furthermore, the process of aging causes a gradual loss of elastin and replacement by collagen, which amplifies the increase in blood pressure [125]. Persistent alteration in conduit artery function and arterial stiffness may predispose a person to hypertension and cardiovascular disease in adulthood.

\section{Perspectives}

Study designs

The associations of fetal growth retardation and low birth weight with cardiovascular disease are not yet fully understood. Methodological issues, such as the role of potential confounders in the associations and the population effect size, should be further examined. Well-designed epidemiological studies are necessary to overcome current methodological issues. Population-based prospective cohort studies starting in the preconceptional period or in early fetal life, in which the offspring is followed from early fetal life until young adulthood, seem to be the most suitable 


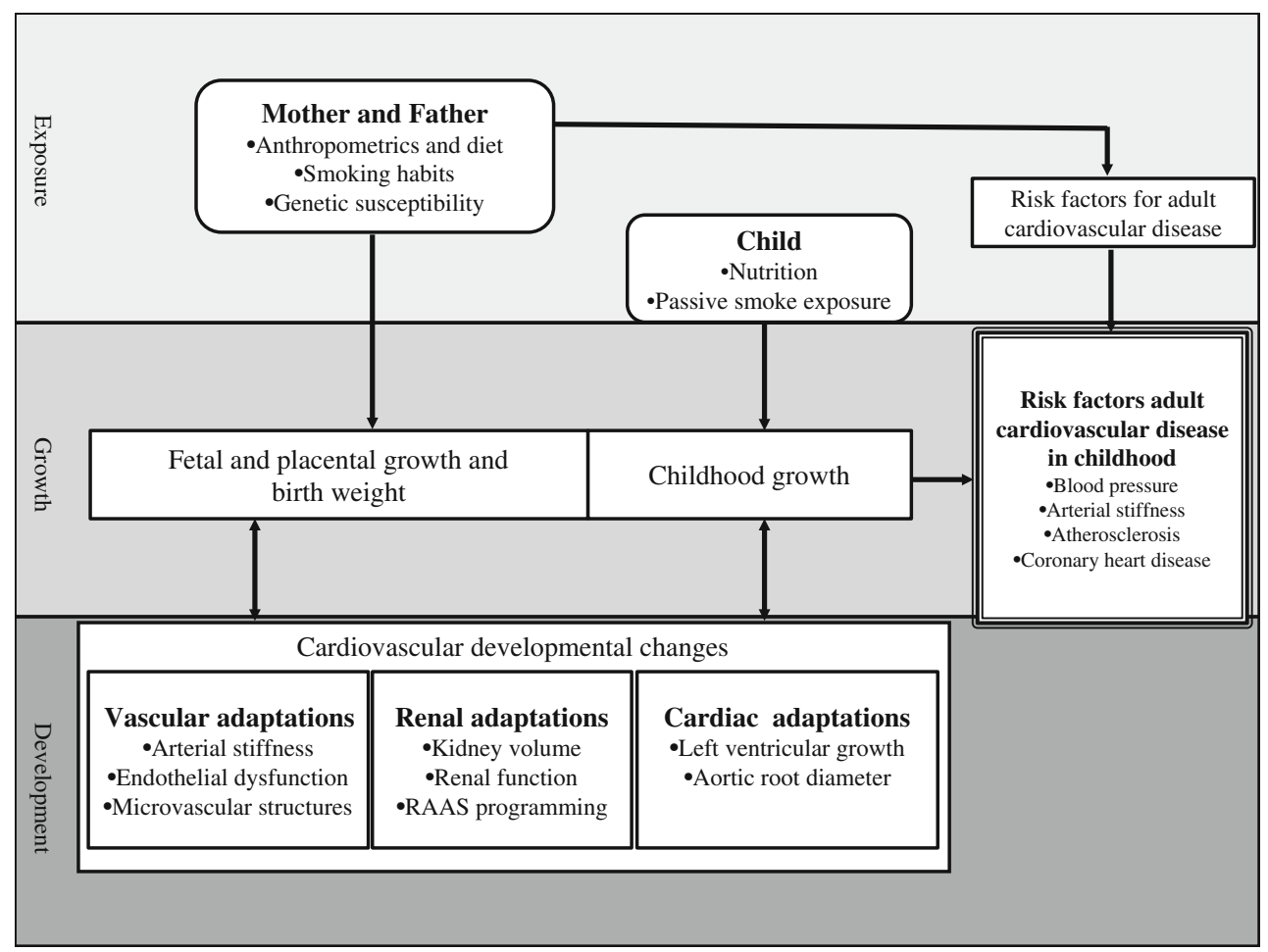

Fig. 1 A developmental origins study model, studying the fetal origins of cardiovascular disease in epidemiological studies. This model presents core associations that have to be studied to unravel the underlying mechanisms of the associations of fetal growth restriction and low birth weight and cardiovascular disease later in life. The upper part shows associations in mother and father, identifying both

epidemiological design (Fig. 1). This epidemiological design is the best design for assuring quality of the data, taking account for potential confounders and identifying growth patterns at risk. Recently, various population-based prospective cohort studies have been started worldwide [126-129]. However, a limitation of this design is the long period needed for the studied adult disease to develop. The design of a retrospective cohort study may lead to an earlier availability of data according to cardiovascular disease. However, this design will not take account of all potential confounders and will probably not be able to study the effects of fetal or early postnatal influences.

The effects of many adverse fetal exposures due to maternal life style habits can only be studied in observational designs. However, for assessing the effects of nutritional exposures on fetal growth restriction and the risk of cardiovascular disease, randomized controlled trials would be the design of choice. For example the impact of calcium, folate and other micronutrients on offspring birth weight and blood pressure is examined in randomized controlled trials $[30,32,130]$. Randomized controlled trials should be able to overcome current methodological issues and identify mechanisms in the causal pathway that underlie the associations. determinants of fetal and postnatal growth patterns and environmental and genetic mechanisms. The lower part demonstrates associations in the offspring that have to identify growth patterns and developmental changes in fetal and early postnatal life, resulting in an increased risk of cardiovascular disease in adulthood. RAAS Renin-angiotensinaldosterone system

Detailed exposure studies

\section{Nutrition}

In Western countries, maternal variation in dietary patterns and intake of micronutrients seems more relevant than a restricted total energy and macronutrient intake for having an effect on fetal growth retardation [131]. Future studies should focus on the intake of particular macronutrients and micronutrients, including calcium, folic acid and homocystein, in specific periods of pregnancy. Identifying critical periods in pregnancy will result in detailed dietary advices aimed at these specific time points in pregnancy. Additionally, dietary patterns during the preconception period have been associated with biomarkers concentrations and related to complex diseases, such as cardiovascular disease [132, 133]. Overall dietary patterns may be easier for the public to interpret or translate into diets.

\section{Genome-wide association studies}

Common genetic variants may explain the associations between growth in early life and diseases in adulthood. 
Large scale genome-wide association studies (GWAS) have revealed links between DNA sequence variation and a growing range of diseases and continuous traits, such as cardiovascular disease and type 2 diabetes [134-136]. The effect of these common genetic variants on growth characteristics and growth patterns may already be present in fetal and early postnatal life. Relating these genetic loci to early growth patterns might identify genes related to both fetal growth retardation and cardiovascular disease.

\section{Epigenetics}

Epigenetics is understood as the heritable changes in gene expression potential that are not caused by changes in DNA sequence [137, 138]. DNA methylation is one of the best understood epigenetic modification and is a key epigenetic contributor to maintenance of gene silencing. $\mathrm{CpG}$ islands are mostly located in the control regions of genes, for example the promoter region of actively transcribed gene, and are generally unmethylated. Methylation of this promoter region leads to decreased binding of transcription factors and thereby to a reduced gene expression [139]. Maternal diet has been shown to dynamically affect DNA methylation status [140]. Methyl-supplemented diets include the methyl donors such as folic acid, vitamin B12, choline, L-methionine and zinc. Studies in sheep showed associations between reductions in the availability of Vitamin B12 and folate during the periconceptual period and alterations in methylation status of $\mathrm{CpG}$ islands in the offspring [141]. This may lead to widespread epigenetic modifications to the genome of the offspring. In humans, lower DNA methylation of the IGF2 gene was reported in adults who have been exposed to the Dutch Famine in the periconceptional period [142]. These results suggest that earlylife environmental conditions can cause epigenetic changes that persist throughout life and could lead to the development of risk factors for hypertension and cardiovascular disease in adult offspring. However, future research is needed to better understand the role of epigenetic dysregulation in the associations between adverse fetal nutritional exposures and diseases in adult life [143]. Since the periconceptional period is a crucial period for establishing and maintaining epigenetic marks, cohort studies starting in the preconceptional period would give important knowledge [144].

\section{Paternal influences}

We discussed substantial affects on fetal programming by maternal prenatal behaviors, specifically by maternal smoking, maternal diet and maternal genetic susceptibility. However, paternal influences, for example paternal genetic susceptibility, could also underlie the pathways of fetal growth retardation and low birth weight to the development of cardiovascular disease in adulthood. Also, comparing maternal and paternal effects provides a method of separating intra-uterine effects from associations related to familial or environmental factors. Similar associations of maternal and paternal exposures with offspring health outcomes suggest that common factors related to the family or environment may drive the associations, rather than intrauterine effects only. Future research is required to compare associations of both maternal and paternal exposures during pregnancy with components of offspring health.

\section{Detailed cardiovascular development studies}

To disentangle the mechanisms underlying the associations of fetal growth restriction and low birth weight with the development of cardiovascular disease, future research should focus on early markers of cardiovascular adaptation. Good repeatability and reproducibility of most left cardiac structures in children measured by $2 \mathrm{D}$ ultrasound is previously demonstrated in large-scale multicenter studies in young children $[145,146]$. However, newer imaging techniques, such as three-dimensional echocardiography and magnetic resonance imaging, can more precisely calculate physiologic variables of interest [147]. In the future, these new imaging techniques offer great opportunities for detailed cardiovascular measurements in epidemiological research. Thereby, subtle developmental cardiovascular changes can be identified already in fetal or early postnatal life. Furthermore, focusing on other biomarkers of cardiac development, including detailed repeated measurements of right cardiac structures, may give newer inside in the pathway leading to the development of cardiovascular disease.

Although there is limited direct evidence that risk factors measured in childhood are predictive of atherosclerosis in adulthood [116, 117], less is known about the associations of fetal and maternal factors during pregnancy and vascular changes in childhood. Endothelial function and structural arterial changes, including arterial resistance and arterial stiffness, can be measured noninvasively en early childhood with high resolution ultrasound to measure brachial artery flow-mediated dilatation and carotid artery intima-media thickness, respectively [148, 149]. Furthermore, future studies should focus on additional markers of vascular structures and function, including retinal arteriolar narrowing. This may lead to peripheral vascular resistance and thereby predispose a person to the development of hypertension and cardiovascular disease [150].

\section{Clinical implications and future research}

The associations between low birth weight and cardiovascular disease in later life seem to be one of the most intriguing and controversial epidemiological findings from 
the last decade and might have clinical and public health implications. However, the effect size of low birth weight on cardiovascular disease and blood pressure in adulthood presented in current studies seems to be small [1, 151]. Furthermore, the specific adverse exposures and underlying mechanisms are not known. Recently, new areas of research in cardiovascular epidemiology have already become prominent. The focus has increasingly been on genes implicated in cardiovascular diseases [152-156]. However, the focus of most of the studies in cardiovascular epidemiology is still on putative risk factors [157-165], with particular focus on nutrition [166-169], on socio-economic factors and health inequalities [170-185], and, more recently, on physical activity [186-189]. In addition, studies focus on methods of cardiovascular studies [190-195] and on frequency measures and trends in risks of cardiovascular morbidity and mortality [196-205]. For further exploring the underlying mechanisms and to assess potentials for clinical implications, research has to move onwards from birth weight association studies to adverse fetal exposures and detailed early cardiovascular development studies. Since plasticity operates across the entire range of environment and leads to multigenerational cycles of disease, any rational approach to health care should start early in life and take a cross-generational perspective [206]. Data of prospective cohort studies confirm the existence of a window of opportunity for intervention in early childhood [207, 208]. The growing awareness of the importance of the preconceptual period, when nutrition can have long-lasting effects without causing any change in birth weight, underscores the importance of healthy nutrition during the prepregnancy period. Research should also focus on identifying individuals at greater risk of later poor health and develop strategies aimed at these specific individuals.

\section{Conclusion}

The associations between low birth weigh and cardiovascular disease are present within the normal and physiologic ranges, and suggest that specific exposures in different periods of fetal and early postnatal life have permanent consequences for cardiovascular growth and function. The mechanisms underlying these associations are not known, but may include environmental and genetic determinants. Future studies should be focused on these mechanisms and epigenetic modifications of specific genes related to cardiovascular development. Furthermore, studies should focus on detailed cardiovascular adaptive responses in fetal life and early childhood by use of new imaging and functional techniques. Eventually results from these studies may lead to improved health in childhood and adulthood by promoting a better fetal environment.
Acknowledgments The Generation R Study is conducted by the Erasmus Medical Center in close collaboration with the School of Law and Faculty of Social Sciences of the Erasmus University Rotterdam, the Municipal Health Service Rotterdam area, Rotterdam, the Rotterdam Homecare Foundation, Rotterdam and the Stichting Trombosedienst \& Artsenlaboratorium Rijnmond (STAR), Rotterdam. We gratefully acknowledge the contribution of general practitioners, hospitals, midwives and pharmacies in Rotterdam. This work was supported by the Erasmus Medical Center, Rotterdam; and the Erasmus University Rotterdam; and the Netherlands Organization for Health Research and Development (ZonMw).

Conflict of interest None declared.

Open Access This article is distributed under the terms of the Creative Commons Attribution Noncommercial License which permits any noncommercial use, distribution, and reproduction in any medium, provided the original author(s) and source are credited.

\section{References}

1. Huxley R, Owen CG, Whincup PH, et al. Is birth weight a risk factor for ischemic heart disease in later life? Am J Clin Nutr. 2007;85:1244-50.

2. Osmond C, Barker DJ, Winter PD, Fall CH, Simmonds SJ. Early growth and death from cardiovascular disease in women. BMJ. 1993;307:1519-24.

3. Lawlor DA, Ronalds G, Clark H, Smith GD, Leon DA. Birth weight is inversely associated with incident coronary heart disease and stroke among individuals born in the 1950s: findings from the aberdeen children of the 1950s prospective cohort study. Circulation. 2005;112:1414-8.

4. Barker DJ. Fetal origins of coronary heart disease. BMJ. 1995; 311:171-4.

5. Barker DJ, Osmond C, Simmonds SJ, Wield GA. The relation of small head circumference and thinness at birth to death from cardiovascular disease in adult life. BMJ. 1993;306:422-6.

6. Frankel S, Elwood P, Sweetnam P, Yarnell J, Smith GD. Birthweight, body-mass index in middle age, and incident coronary heart disease. Lancet. 1996;348:1478-80.

7. Rich-Edwards JW, Stampfer MJ, Manson JE, et al. Birth weight and risk of cardiovascular disease in a cohort of women followed up since 1976. BMJ. 1997;315:396-400.

8. Barker DJ, Osmond C. Infant mortality, childhood nutrition, and ischaemic heart disease in England and Wales. Lancet. 1986;1: 1077-81.

9. Gluckman PD, Hanson MA, Cooper C, Thornburg KL. Effect of in utero and early-life conditions on adult health and disease. N Engl J Med. 2008;359:61-73.

10. Bateson P, Barker D, Clutton-Brock T, et al. Developmental plasticity and human health. Nature. 2004;430:419-21.

11. Gluckman PD, Hanson MA, Morton SM, Pinal CS. Life-long echoes-a critical analysis of the developmental origins of adult disease model. Biol Neonate. 2005;87:127-39.

12. Brooks AA, Johnson MR, Steer PJ, Pawson ME, Abdalla HI. Birth weight: nature or nurture? Early Hum Dev. 1995;42: 29-35.

13. Hokken-Koelega AC, De Ridder MA, Lemmen RJ, Den Hartog H, De Muinck Keizer-Schrama SM, Drop SL. Children born small for gestational age: do they catch up? Pediatr Res. 1995;38: 267-71.

14. Eriksson JG, Forsen T, Tuomilehto J, Winter PD, Osmond C, Barker DJ. Catch-up growth in childhood and death from coronary heart disease: longitudinal study. BMJ. 1999;318:427-31. 
15. Eriksson JG, Forsen T, Tuomilehto J, Osmond C, Barker DJ. Early growth and coronary heart disease in later life: longitudinal study. BMJ. 2001;322:949-53.

16. Roseboom TJ, van der Meulen JH, Osmond C, et al. Coronary heart disease after prenatal exposure to the Dutch famine, 1944-45. Heart. 2000;84:595-8.

17. Bergmann MM, Flagg EW, Miracle-McMahill HL, Boeing H. Energy intake and net weight gain in pregnant women according to body mass index (BMI) status. Int J Obes Relat Metab Disord. 1997;21:1010-7.

18. Siega-Riz AM, Adair LS. Biological determinants of pregnancy weight gain in a Filipino population. Am J Clin Nutr. 1993;57: 365-72.

19. Kabiru W, Raynor BD. Obstetric outcomes associated with increase in BMI category during pregnancy. Am J Obstet Gynecol. 2004;191:928-32.

20. Jensen DM, Damm P, Sorensen B, et al. Pregnancy outcome and prepregnancy body mass index in 2459 glucose-tolerant Danish women. Am J Obstet Gynecol. 2003;189:239-44.

21. Ay L, Kruithof CJ, Bakker R, et al. Maternal anthropometrics are associated with fetal size in different periods of pregnancy and at birth. The Generation R Study. BJOG. 2009;116: 953-63.

22. Geelhoed JJ, Van Osch-Gevers L, Verburg BO, et al. Maternal anthropometrics in pregnancy are associated with left ventricular mass in infancy. The Generation R Study. Pediatr Res. 2008;63: $62-6$.

23. Mamun AA, O'Callaghan M, Callaway L, Williams G, Najman J, Lawlor DA. Associations of gestational weight gain with offspring body mass index and blood pressure at 21 years of age: evidence from a birth cohort study. Circulation. 2009;119: $1720-7$.

24. King JC. Maternal obesity, metabolism, and pregnancy outcomes. Annu Rev Nutr. 2006;26:271-91.

25. Fowden AL. The role of insulin in prenatal growth. J Dev Physiol. 1989;12:173-82.

26. Sparen P, Vagero D, Shestov DB, et al. Long term mortality after severe starvation during the siege of Leningrad: prospective cohort study. BMJ. 2004;328:11.

27. Hawkesworth S, Prentice AM, Fulford AJ, Moore SE. Maternal protein-energy supplementation does not affect adolescent blood pressure in the Gambia. Int J Epidemiol. 2009;38:119-27.

28. Huh SY, Rifas-Shiman SL, Kleinman KP, Rich-Edwards JW, Lipshultz SE, Gillman MW. Maternal protein intake is not associated with infant blood pressure. Int J Epidemiol. 2005;34: 378-84.

29. Kinra S, Rameshwar Sarma KV, Ghafoorunissa, et al. Effect of integration of supplemental nutrition with public health programmes in pregnancy and early childhood on cardiovascular risk in rural Indian adolescents: long term follow-up of Hyderabad nutrition trial. BMJ. 2008;337:a605.

30. Belizan JM, Villar J, Bergel E, et al. Long-term effect of calcium supplementation during pregnancy on the blood pressure of offspring: follow up of a randomised controlled trial. BMJ. 1997;315:281-5.

31. Gillman MW, Rifas-Shiman SL, Kleinman KP, Rich-Edwards JW, Lipshultz SE. Maternal calcium intake and offspring blood pressure. Circulation. 2004;110:1990-5.

32. van Mierlo LA, Arends LR, Streppel MT, et al. Blood pressure response to calcium supplementation: a meta-analysis of randomized controlled trials. J Hum Hypertens. 2006;20:571-80.

33. Bakker R, Rifas-Shiman SL, Kleinman KP, Lipshultz SE, Gillman MW. Maternal calcium intake during pregnancy and blood pressure in the offspring at age 3 years: a follow-up analysis of the Project Viva cohort. Am J Epidemiol. 2008;168: 1374-80.
34. Morley R, Carlin JB, Dwyer T. Maternal calcium supplementation and cardiovascular risk factors in twin offspring. Int $\mathrm{J}$ Epidemiol. 2004;33:1304-9.

35. Moat SJ, Lang D, McDowell IF, et al. Folate, homocysteine, endothelial function and cardiovascular disease. J Nutr Biochem. 2004;15:64-79.

36. de Bree A, van Mierlo LA, Draijer R. Folic acid improves vascular reactivity in humans: a meta-analysis of randomized controlled trials. Am J Clin Nutr. 2007;86:610-7.

37. Martin H, Lindblad B, Norman M. Endothelial function in newborn infants is related to folate levels and birth weight. Pediatrics. 2007;119:1152-8.

38. Walker JJ. Pre-eclampsia. Lancet. 2000;356:1260-5.

39. Godfrey KM, Barker DJ. Fetal nutrition and adult disease. Am J Clin Nutr. 2000;71:1344S-52S.

40. Smith GC, Pell JP, Walsh D. Pregnancy complications and maternal risk of ischaemic heart disease: a retrospective cohort study of 129, 290 births. Lancet. 2001;357:2002-6.

41. Callaway LK, McIntyre HD, O'Callaghan M, Williams GM, Najman JM, Lawlor DA. The association of hypertensive disorders of pregnancy with weight gain over the subsequent 21 years: findings from a prospective cohort study. Am J Epidemiol. 2007; 166:421-8.

42. Tenhola S, Rahiala E, Martikainen A, Halonen P, Voutilainen R. Blood pressure, serum lipids, fasting insulin, and adrenal hormones in 12-year-old children born with maternal preeclampsia. J Clin Endocrinol Metab. 2003;88:1217-22.

43. Baschat AA, Hecher K. Fetal growth restriction due to placental disease. Semin Perinatol. 2004;28:67-80.

44. Higgins S. Smoking in pregnancy. Curr Opin Obstet Gynecol. 2002;14:145-51.

45. Ong KK, Preece MA, Emmett PM, Ahmed ML, Dunger DB. Size at birth and early childhood growth in relation to maternal smoking, parity and infant breast-feeding: longitudinal birth cohort study and analysis. Pediatr Res. 2002;52:863-7.

46. Jaddoe VW, Verburg BO, de Ridder MA, et al. Maternal smoking and fetal growth characteristics in different periods of pregnancy: the Generation R Study. Am J Epidemiol. 2007;165: 1207-15.

47. Larsen LG, Clausen HV, Jonsson L. Stereologic examination of placentas from mothers who smoke during pregnancy. Am J Obstet Gynecol. 2002;186:531-7.

48. Morrow RJ, Ritchie JW, Bull SB. Maternal cigarette smoking: the effects on umbilical and uterine blood flow velocity. Am J Obstet Gynecol. 1988;159:1069-71.

49. Blake KV, Gurrin LC, Evans SF, et al. Maternal cigarette smoking during pregnancy, low birth weight and subsequent blood pressure in early childhood. Early Hum Dev. 2000;57: 137-47.

50. Brion MJ, Leary SD, Lawlor DA, Smith GD, Ness AR. Modifiable maternal exposures and offspring blood pressure: a review of epidemiological studies of maternal age, diet, and smoking. Pediatr Res. 2008;63:593-8.

51. Brion MJ, Leary SD, Smith GD, Ness AR. Similar associations of parental prenatal smoking suggest child blood pressure is not influenced by intrauterine effects. Hypertension. 2007;49: 1422-8.

52. Geelhoed JJ. Early influences on cardiovascular and renal development [Dissertation]. Rotterdam, The Netherlands: Erasmus Medical Center; 2010. p. 299.

53. Lampl M, Kuzawa CW, Jeanty P. Growth patterns of the heart and kidney suggest inter-organ collaboration in facultative fetal growth. Am J Hum Biol. 2005;17:178-94.

54. Severi FM, Rizzo G, Bocchi C, D’Antona D, Verzuri MS, Arduini D. Intrauterine growth retardation and fetal cardiac function. Fetal Diagn Ther. 2000;15:8-19. 
55. Hattersley AT, Tooke JE. The fetal insulin hypothesis: an alternative explanation of the association of low birthweight with diabetes and vascular disease. Lancet. 1999;353:1789-92.

56. Fowden AL. The insulin-like growth factors and feto-placental growth. Placenta. 2003;24:803-12.

57. Geelhoed JJ, Mook-Kanamori DO, Witteman JC, et al. Variation in the IGF1 gene and growth in foetal life and infancy. The Generation R Study. Clin Endocrinol. 2008;68:382-9.

58. Mook-Kanamori DO, Miranda Geelhoed JJ, Steegers EA, et al. Insulin gene variable number of tandem repeats is not associated with weight from fetal life until infancy: the Generation $\mathrm{R}$ Study. Eur J Endocrinol. 2007;157:741-8.

59. Bennett AJ, Sovio U, Ruokonen A, et al. No evidence that established type 2 diabetes susceptibility variants in the PPARG and KCNJ11 genes have pleiotropic effects on early growth. Diabetologia. 2008;51:82-5.

60. Pfab T, Poralla C, Richter CM, et al. Fetal and maternal peroxisome proliferator-activated receptor gamma2 Pro12Ala does not influence birth weight. Obesity. 2006;14:1880-5.

61. Mook-Kanamori DO, Steegers EA, Uitterlinden AG, et al. Breast-feeding modifies the association of PPARgamma2 polymorphism Pro12Ala with growth in early life: the Generation R Study. Diabetes. 2009;58:992-8.

62. Freathy RM, Bennett AJ, Ring SM, et al. Type 2 diabetes risk alleles are associated with reduced size at birth. Diabetes. 2009;58:1428-33.

63. Eriksson J, Lindi V, Uusitupa $M$, et al. The effects of the Pro12Ala polymorphism of the PPARgamma-2 gene on lipid metabolism interact with body size at birth. Clin Genet. 2003;64:366-70.

64. Yliharsila H, Eriksson JG, Forsen T, et al. Interactions between peroxisome proliferator-activated receptor-gamma 2 gene polymorphisms and size at birth on blood pressure and the use of antihypertensive medication. J Hypertens. 2004;22:1283-7.

65. Benediktsson R, Lindsay RS, Noble J, Seckl JR, Edwards CR. Glucocorticoid exposure in utero: new model for adult hypertension. Lancet. 1993;341:339-41.

66. Barker DJ, Bull AR, Osmond C, Simmonds SJ. Fetal and placental size and risk of hypertension in adult life. BMJ. 1990;301:259-62.

67. Whincup PH, Kaye SJ, Owen CG, et al. Birth weight and risk of type 2 diabetes: a systematic review. JAMA. 2008;300: 2886-97.

68. van den Akker EL, Koper JW, van Rossum EF, et al. Glucocorticoid receptor gene and risk of cardiovascular disease. Arch Intern Med. 2008;168:33-9.

69. Geelhoed MJ, Steegers EA, Koper JW, van Rossum EF, Moll HA, Raat H, Tiemeier H, Hofman A, Jaddoe VW. Glucocorticoid receptor gene polymorphisms do not affect growth in fetal and early postnatal life. The Generation R Study. BMC Med Genet. 2010;11:39.

70. Veille JC, Smith N, Zaccaro D. Ventricular filling patterns of the right and left ventricles in normally grown fetuses: a longitudinal follow-up study from early intrauterine life to age 1 year. Am J Obstet Gynecol. 1999;180:849-58.

71. Schulman H. The clinical implications of Doppler ultrasound analysis of the uterine and umbilical arteries. Am J Obstet Gynecol. 1987;156:889-93.

72. Rizzo G, Arduini D, Romanini C, Mancuso S. Doppler echocardiographic assessment of atrioventricular velocity waveforms in normal and small-for-gestational-age fetuses. Br J Obstet Gynecol. 1988;95:65-9.

73. Verburg BO, Jaddoe VW, Wladimiroff JW, Hofman A, Witteman JC, Steegers EA. Fetal hemodynamic adaptive changes related to intrauterine growth: the Generation R Study. Circulation. 2008;117: 649-59.
74. Geelhoed JJ, Steegers EA, van Osch-Gevers L, Verburg BO, Hofman A, Witteman JC, van der Heijden AJ, Helbing WA, Jaddoe VW. Cardiac structures track during the first 2 years of life and are associated with fetal growth and hemodynamics: the Generation R Study. Am Heart J. 2009;158:71-7.

75. Jiang B, Godfrey KM, Martyn CN, Gale CR. Birth weight and cardiac structure in children. Pediatrics. 2006;117:e257-61.

76. Vijayakumar M, Fall CH, Osmond C, Barker DJ. Birth weight, weight at one year, and left ventricular mass in adult life. $\mathrm{Br}$ Heart J. 1995;73:363-7.

77. Zureik M, Bonithon-Kopp C, Lecomte E, Siest G, Ducimetiere P. Weights at birth and in early infancy, systolic pressure, and left ventricular structure in subjects aged 8-24 years. Hypertension. 1996;27:339-45.

78. Janz KF, Dawson JD, Mahoney LT. Predicting heart growth during puberty: the Muscatine Study. Pediatrics. 2000;105:E63.

79. Urbina EM, Gidding SS, Bao W, Pickoff AS, Berdusis K, Berenson GS. Effect of body size, ponderosity, and blood pressure on left ventricular growth in children and young adults in the Bogalusa Heart Study. Circulation. 1995;91:2400-6.

80. Levy D, Garrison RJ, Savage DD, Kannel WB, Castelli WP. Prognostic implications of echocardiographically determined left ventricular mass in the Framingham Heart Study. N Engl J Med. 1990;322:1561-6.

81. Toprak A, Wang H, Chen W, Paul T, Srinivasan S, Berenson G. Relation of childhood risk factors to left ventricular hypertrophy (eccentric or concentric) in relatively young adulthood (from the Bogalusa Heart Study). Am J Cardiol. 2008;101:1621-5.

82. Nigram SK, Aperia AC, Brenner BM. Development and maturation of the kidney. In: Brenner BM, editor. Brenner and Rector's the kidney, vol. 5. Philadelphia: WB Saunders Company; 1996. p. 72-98.

83. Guron G, Friberg P. An intact renin-angiotensin system is a prerequisite for normal renal development. J Hypertens. 2000;18: 123-37.

84. Hammerman MR. Growth factors in renal development. Semin Nephrol. 1995;15:291-9.

85. Merlet-Benichou C. Influence of fetal environment on kidney development. Int J Dev Biol. 1999;43:453-6.

86. Hinchliffe SA, Sargent PH, Howard CV, Chan YF, van Velzen D. Human intrauterine renal growth expressed in absolute number of glomeruli assessed by the disector method and Cavalieri principle. Lab Invest. 1991;64:777-84.

87. Nyengaard JR, Bendtsen TF. Glomerular number and size in relation to age, kidney weight, and body surface in normal man. Anat Rec. 1992;232:194-201.

88. Hughson M, Farris AB III, Douglas-Denton R, Hoy WE, Bertram JF. Glomerular number and size in autopsy kidneys: the relationship to birth weight. Kidney Int. 2003;63:2113-22.

89. Hughson MD, Douglas-Denton R, Bertram JF, Hoy WE. Hypertension, glomerular number, and birth weight in African Americans and white subjects in the southeastern United States. Kidney Int. 2006;69:671-8.

90. Keller G, Zimmer G, Mall G, Ritz E, Amann K. Nephron number in patients with primary hypertension. $\mathrm{N}$ Engl $\mathrm{J}$ Med. 2003;348:101-8.

91. Langley-Evans SC, Welham SJ, Jackson AA. Fetal exposure to a maternal low protein diet impairs nephrogenesis and promotes hypertension in the rat. Life Sci. 1999;64:965-74.

92. Lelievre-Pegorier M, Vilar J, Ferrier ML, et al. Mild vitamin A deficiency leads to inborn nephron deficit in the rat. Kidney Int. 1998;54:1455-62.

93. Bassan H, Trejo LL, Kariv N, et al. Experimental intrauterine growth retardation alters renal development. Pediatr Nephrol. 2000;15:192-5. 
94. Celsi G, Kistner A, Aizman R, et al. Prenatal dexamethasone causes oligonephronia, sodium retention, and higher blood pressure in the offspring. Pediatr Res. 1998;44:317-22.

95. Hinchliffe SA, Lynch MR, Sargent PH, Howard CV, Van Velzen $D$. The effect of intrauterine growth retardation on the development of renal nephrons. Br J Obstet Gynaecol. 1992;99:296-301.

96. Manalich R, Reyes L, Herrera M, Melendi C, Fundora I. Relationship between weight at birth and the number and size of renal glomeruli in humans: a histomorphometric study. Kidney Int. 2000;58:770-3.

97. Schmidt IM, Chellakooty M, Boisen KA, et al. Impaired kidney growth in low-birth-weight children: distinct effects of maturity and weight for gestational age. Kidney Int. 2005;68:731-40.

98. Hotoura E, Argyropoulou M, Papadopoulou F, et al. Kidney development in the first year of life in small-for-gestational-age preterm infants. Pediatr Radiol. 2005;35:991-4.

99. Giapros V, Drougia A, Hotoura E, Papadopoulou F, Argyropoulou M, Andronikou S. Kidney growth in small-for-gestational-age infants: evidence of early accelerated renal growth. Nephrol Dial Transplant. 2006;21:3422-7.

100. Geelhoed JJ, Verburg BO, Nauta J, et al. Tracking and determinants of kidney size from fetal life until the age of 2 years: the Generation R Study. Am J Kidney Dis. 2009;53:248-58.

101. Verburg BO, Geelhoed JJ, Steegers EA, et al. Fetal kidney volume and its association with growth and blood flow in fetal life: the Generation R Study. Kidney Int. 2007;72:754-61.

102. Brenner BM, Chertow GM. Congenital oligonephropathy and the etiology of adult hypertension and progressive renal injury. Am J Kidney Dis. 1994;23:171-5.

103. Brenner BM, Lawler EV, Mackenzie HS. The hyperfiltration theory: a paradigm shift in nephrology. Kidney Int. 1996;49:1774-7.

104. Lackland DT, Bendall HE, Osmond C, Egan BM, Barker DJ. Low birth weights contribute to high rates of early-onset chronic renal failure in the Southeastern United States. Arch Intern Med. 2000;160:1472-6.

105. Pinto-Sietsma SJ, Janssen WM, Hillege HL, Navis G, De Zeeuw $\mathrm{D}$, De Jong PE. Urinary albumin excretion is associated with renal functional abnormalities in a nondiabetic population. J Am Soc Nephrol. 2000;11:1882-8.

106. Hoy WE, Rees M, Kile E, et al. Low birthweight and renal disease in Australian aborigines. Lancet. 1998;352:1826-7.

107. Ramirez SP, Hsu SI, McClellan W. Low body weight is a risk factor for proteinuria in multiracial Southeast Asian pediatric population. Am J Kidney Dis. 2001;38:1045-54.

108. van Hooft IM, Grobbee DE, Derkx FH, de Leeuw PW, Schalekamp MA, Hofman A. Renal hemodynamics and the renin-angiotensinaldosterone system in normotensive subjects with hypertensive and normotensive parents. N Engl J Med. 1991;324:1305-11.

109. Konje JC, Bell SC, Morton JJ, de Chazal R, Taylor DJ. Human fetal kidney morphometry during gestation and the relationship between weight, kidney morphometry and plasma active renin concentration at birth. Clin Sci. 1996;91:169-75.

110. van den Wijngaard JA, Groenenberg IA, Wladimiroff JW, Hop WC. Cerebral Doppler ultrasound of the human fetus. Br J Obstet Gynaecol. 1989;96:845-9.

111. Ross R. Atherosclerosis - an inflammatory disease. N Engl J Med. 1999;340:115-26.

112. Ross R. The pathogenesis of atherosclerosis: a perspective for the 1990s. Nature. 1993;362:801-9.

113. Jarvisalo MJ, Jartti L, Nanto-Salonen K, et al. Increased aortic intima-media thickness: a marker of preclinical atherosclerosis in high-risk children. Circulation. 2001;104:2943-7.

114. Mahoney LT, Lauer RM, Lee J, Clarke WR. Factors affecting tracking of coronary heart disease risk factors in children. The Muscatine Study. Ann N Y Acad Sci. 1991;623:120-32.
115. Webber LS, Srinivasan SR, Wattigney WA, Berenson GS. Tracking of serum lipids and lipoproteins from childhood to adulthood. The Bogalusa Heart Study. Am J Epidemiol. 1991;133:884-99.

116. Davis PH, Dawson JD, Riley WA, Lauer RM. Carotid intimalmedial thickness is related to cardiovascular risk factors measured from childhood through middle age: the Muscatine Study. Circulation. 2001;104:2815-9.

117. Mahoney LT, Burns TL, Stanford W, et al. Coronary risk factors measured in childhood and young adult life are associated with coronary artery calcification in young adults: the Muscatine Study. J Am Coll Cardiol. 1996;27:277-84.

118. Leeson CP, Kattenhorn M, Morley R, Lucas A, Deanfield JE. Impact of low birth weight and cardiovascular risk factors on endothelial function in early adult life. Circulation. 2001;103:1264-8.

119. Martin H, Hu J, Gennser G, Norman M. Impaired endothelial function and increased carotid stiffness in 9-year-old children with low birthweight. Circulation. 2000;102:2739-44.

120. Gardiner HM. Intrauterine programming of the cardiovascular system. Ultrasound Obstet Gynecol. 2008;32:481-4.

121. Gardiner H, Brodszki J, Marsal K. Ventriculovascular physiology of the growth-restricted fetus. Ultrasound Obstet Gynecol. 2001; 18:47-53.

122. Montgomery AA, Ben-Shlomo Y, McCarthy A, Davies D, Elwood P, Smith GD. Birth size and arterial compliance in young adults. Lancet. 2000;355:2136-7.

123. Cheung YF, Wong KY, Lam BC, Tsoi NS. Relation of arterial stiffness with gestational age and birth weight. Arch Dis Child. 2004;89:217-21.

124. Mzayek F, Sherwin R, Hughes J, et al. The association of birth weight with arterial stiffness at mid-adulthood: the Bogalusa Heart Study. J Epidemiol Community Health. 2009;63:729-33.

125. Martyn CN, Greenwald SE. Impaired synthesis of elastin in walls of aorta and large conduit arteries during early development as an initiating event in pathogenesis of systemic hypertension. Lancet. 1997;350:953-5.

126. Jaddoe VW, van Duijn CM, van der Heijden AJ, et al. The Generation R Study: design and cohort update until the age of 4 years. Eur J Epidemiol. 2008;23:801-11.

127. Golding J, Pembrey M, Jones R. ALSPAC - the avon longitudinal study of parents and children. I. Study methodology. Paediatr Perinat Epidemiol. 2001;15:74-87.

128. Magnus P, Irgens LM, Haug K, Nystad W, Skjaerven R, Stoltenberg C. Cohort profile: the Norwegian mother and child cohort study (MoBa). Int J Epidemiol. 2006;35:1146-50.

129. Olsen J, Melbye M, Olsen SF, et al. The Danish National Birth Cohort-its background, structure and aim. Scand J Public Health. 2001;29:300-7.

130. Zeng L, Dibley MJ, Cheng Y, et al. Impact of micronutrient supplementation during pregnancy on birth weight, duration of gestation, and perinatal mortality in rural western China: double blind cluster randomised controlled trial. BMJ. 2008;337:a2001.

131. Vujkovic M, Ocke MC, van der Spek PJ, Yazdanpanah N, Steegers EA, Steegers-Theunissen RP. Maternal Western dietary patterns and the risk of developing a cleft lip with or without a cleft palate. Obstet Gynecol. 2007;110:378-84.

132. Kerver JM, Yang EJ, Bianchi L, Song WO. Dietary patterns associated with risk factors for cardiovascular disease in healthy US adults. Am J Clin Nutr. 2003;78:1103-10.

133. Weikert C, Hoffmann K, Dierkes J, et al. A homocysteine metabolism-related dietary pattern and the risk of coronary heart disease in two independent German study populations. J Nutr. 2005;135:1981-8.

134. Cho YS, Go MJ, Kim YJ, et al. A large-scale genome-wide association study of Asian populations uncovers genetic factors influencing eight quantitative traits. Nat Genet. 2009;41:527-34. 
135. Levy D, Ehret GB, Rice K, et al. Genome-wide association study of blood pressure and hypertension. Nat Genet. 2009;41: 677-87.

136. Wang Y, O'Connell JR, McArdle PF, et al. From the cover: whole-genome association study identifies STK39 as a hypertension susceptibility gene. Proc Natl Acad Sci USA. 2009;106: 226-31.

137. Waterland RA, Michels KB. Epigenetic epidemiology of the developmental origins hypothesis. Annu Rev Nutr. 2007;27: 363-88.

138. Waterland RA. Is epigenetics an important link between early life events and adult disease? Horm Res. 2009;71(Suppl 1):13-6.

139. Goldberg AD, Allis CD, Bernstein E. Epigenetics: a landscape takes shape. Cell. 2007;128:635-8.

140. Waterland RA. Assessing the effects of high methionine intake on DNA methylation. J Nutr. 2006;136:1706S-10S.

141. Sinclair KD, Allegrucci C, Singh R, et al. DNA methylation, insulin resistance, and blood pressure in offspring determined by maternal periconceptional B vitamin and methionine status. Proc Natl Acad Sci USA. 2007;104:19351-6.

142. Heijmans BT, Tobi EW, Stein AD, et al. Persistent epigenetic differences associated with prenatal exposure to famine in humans. Proc Natl Acad Sci USA. 2008;105:17046-9.

143. Nafee TM, Farrell WE, Carroll WD, Fryer AA, Ismail KM. Epigenetic control of fetal gene expression. BJOG. 2008;115: 158-68.

144. Inskip HM, Godfrey KM, Robinson SM, Law CM, Barker DJ, Cooper C. Cohort profile: the Southampton women's survey. Int J Epidemiol. 2006;35:42-8.

145. Lipshultz SE, Easley KA, Orav EJ, et al. Reliability of multicenter pediatric echocardiographic measurements of left ventricular structure and function: the prospective $\mathrm{P}(2) \mathrm{C}(2) \mathrm{HIV}$ study. Circulation. 2001;104:310-6.

146. Geelhoed MJ, Snijders SP, Kleyburg-Linkers VE, Steegers EA, van Osch-Gevers L, Jaddoe VW. Reliability of echocardiographic measurements of left cardiac structures in healthy children. Cardiol Young. 2009;19:494-500.

147. Jacobs LD, Salgo IS, Goonewardena S, et al. Rapid online quantification of left ventricular volume from real-time threedimensional echocardiographic data. Eur Heart J. 2006;27: 460-8.

148. Halcox JP, Donald AE, Ellins E, et al. Endothelial function predicts progression of carotid intima-media thickness. Circulation. 2009;119:1005-12.

149. Lorenz MW, Markus HS, Bots ML, Rosvall M, Sitzer M. Prediction of clinical cardiovascular events with carotid intimamedia thickness: a systematic review and meta-analysis. Circulation. 2007;115:459-67.

150. Ikram MK, Witteman JC, Vingerling JR, Breteler MM, Hofman A, de Jong PT. Retinal vessel diameters and risk of hypertension: the Rotterdam Study. Hypertension. 2006;47:189-94.

151. Huxley R, Owen CG, Whincup PH, Cook DG, Colman S, Collins R. Birth weight and subsequent cholesterol levels: exploration of the "fetal origins" hypothesis. JAMA. 2004;292:2755-64.

152. Danesh J, CRP CHD Genet Collaborat, Hingorani A, et al. Collaborative pooled analysis of data on C-reactive protein gene variants and coronary disease: judging causality by Mendelian randomisation. Eur J Epidemiol. 2008;23:531-40.

153. Niemiec $\mathrm{P}$, Zak I, Wita K. The M235T polymorphism of the AGT gene modifies the risk of coronary artery disease associated with the presence of hypercholesterolemia. Eur J Epidemiol. 2008;23: 349-54.

154. Mao RF, Fan YH, Chen F, et al. Genetic polymorphism of MTHFR G1793A in Chinese populations. Eur J Epidemiol. 2008; 23:363-8.
155. Silva MCP, Janssens ACJW, Hofman A, et al. Apolipoprotein E gene is related to mortality only in normal weight individuals: the Rotterdam Study. Eur J Epidemiol. 2008;23:135-42.

156. Andreotti G, Menashe I, Chen J, et al. Genetic determinants of serum lipid levels in Chinese subjects: a population-based study in Shanghai, China. Eur J Epidemiol. 2009;24:763-74.

157. Winkelmayer WC, Bucsics AE, Schautzer A, et al. Use of recommended medications after myocardial infarction in Austria. Eur J Epidemiol. 2008;23:153-62.

158. Spencer EA, Pirie KL, Stevens RJ, et al. Diabetes and modifiable risk factors for cardiovascular disease: the prospective Million Women Study. Eur J Epidemiol. 2008;23:793-9.

159. Prugger C, Wellmann J, Heidrich J, Brand-Herrmann SM, Keil U. Cardiovascular risk factors and mortality in patients with coronary heart disease. Eur J Epidemiol. 2008;23:731-7.

160. Reuser M, Bonneux L, Willekens F. The burden of mortality of obesity at middle and old age is small. A life table analysis of the US Health and Retirement Survey. Eur J Epidemiol. 2008;23: 601-7.

161. Oliveira A, Barros H, Azevedo A, Bastos J, Lopes C. Impact of risk factors for non-fatal acute myocardial infarction. Eur $\mathbf{J}$ Epidemiol. 2009;24:425-32.

162. Saleheen D, Zaidi M, Rasheed A, et al. The Pakistan risk of myocardial infarction study: a resource for the study of genetic, lifestyle and other determinants of myocardial infarction in South Asia. Eur J Epidemiol. 2009;24:329-38.

163. Greiser KH, Kluttig A, Schumann B, et al. Cardiovascular diseases, risk factors and short-term heart rate variability in an elderly general population: the CARLA study 2002-2006. Eur J Epidemiol. 2009;24:123-42.

164. Turin TC, Kita Y, Rumana N, et al. Incidence, admission and casefatality of acute myocardial infarction: weekend versus weekday in a Japanese population: 16-year results from Takashima AMI Registry (1988-2003). Eur J Epidemiol. 2009;24:93-100.

165. Osler M, Lund R, Kriegbaum M, Andersen AM. The influence of birth weight and body mass in early adulthood on early coronary heart disease risk among Danish men born in 1953. Eur J Epidemiol. 2009;24:57-61.

166. Lawlor DA, Cooper AR, Bain C, et al. Associations of birth size and duration of breast feeding with cardiorespiratory fitness in childhood: findings from the avon longitudinal study of parents and children (ALSPAC). Eur J Epidemiol. 2008;23:411-22.

167. Britton A, Malik M, Marmot M. The cardioprotective effects of alcohol consumption: does cardiac autonomic function play a role? Eur J Epidemiol. 2008;23:105-8.

168. Zatonski W, Campos H, Willett W. Rapid declines in coronary heart disease mortality in Eastern Europe are associated with increased consumption of oils rich in alpha-linolenic acid. Eur $\mathbf{J}$ Epidemiol. 2008;23:3-10.

169. Trichopoulou A, Bamia C, Norat T, et al. Modified Mediterranean diet and survival after myocardial infarction: the EPICElderly study. Eur J Epidemiol. 2008;23:871-81.

170. McFadden E, Luben R, Wareham N, et al. Occupational social class, educational level, smoking and body mass index, and cause-specific mortality in men and women: a prospective study in the European prospective investigation of cancer and nutrition in Norfolk (EPIC-Norfolk) cohort. Eur J Epidemiol. 2008;23: 511-22.

171. Laszlo KD, Janszky I, Ahnve S. Income and recurrent events after a coronary event in women. Eur J Epidemiol. 2008;23: 669-80.

172. Lawlor DA, Batty GD, Clark H, et al. Association of childhood intelligence with risk of coronary heart disease and stroke: findings from the aberdeen children of the 1950s cohort study. Eur J Epidemiol. 2008;23:695-906. 
173. McFadden E, Luben R, Wareham N, et al. Occupational social class, risk factors and cardiovascular disease incidence in men and women: a prospective study in the European prospective investigation of cancer and nutrition in Norfolk (EPIC-Norfolk) cohort. Eur J Epidemiol. 2008;23:449-58.

174. Strandhagen E, Berg C, Lissner L, et al. Selection bias in a population survey with registry linkage: potential effect on socioeconomic gradient in cardiovascular risk. Eur J Epidemiol. 2010;25:163-72.

175. Gasparrini A, Gorini G, Barchielli A. On the relationship between smoking bans and incidence of acute myocardial infarction. Eur J Epidemiol. 2009;24:597-602.

176. Schneider C, Bothner U, Jick SS, Meier CR. Chronic obstructive pulmonary disease and the risk of cardiovascular diseases. Eur J Epidemiol. 2010;25:253-60.

177. Wiesbauer F, Blessberger H, Goliasch G, et al. Elevated risk of myocardial infarction in very young immigrants from former Yugoslavia. Eur J Epidemiol. 2009;24:691-6.

178. Regidor E, Astasio P, Calle ME, Martínez D, Ortega P, Domínguez $\mathrm{V}$. The association between birthplace in different regions of the world and cardiovascular mortality among residents of Spain. Eur J Epidemiol. 2009;24:503-12.

179. Fallah N, Mohammad K, Nourijelyani K, et al. Nonlinear association between serum testosterone levels and coronary artery disease in Iranian men. Eur J Epidemiol. 2009;24:297-306.

180. Vikan T, Johnsen SH, Schirmer H, Njølstad I, Svartberg J. Endogenous testosterone and the prospective association with carotid atherosclerosis in men: the Troms $\emptyset$ study. Eur J Epidemiol. 2009;24:289-95.

181. Orsini N, Bellocco R, Bottai M, et al. Validity of self-reported total physical activity questionnaire among older women. Eur $\mathrm{J}$ Epidemiol. 2008;23:661-7.

182. Pearce MS, Relton CL, Parker L, Unwin NC. Sex differences in the association between infant feeding and blood cholesterol in later life: the Newcastle thousand families cohort study at age 49-51 years. Eur J Epidemiol. 2009;24:375-80.

183. Tasevska-Dinevska G, Kennedy LM, Nilsson PM, Willenheimer R. Gender aspects on heart failure incidence and mortality in a middle-aged, urban, community-based population sample: the Malmö preventive project. Eur J Epidemiol. 2009;24:249-57.

184. Dragano N, Hoffmann B, Stang A, et al. Subclinical coronary atherosclerosis and neighbourhood deprivation in an urban region. Eur J Epidemiol. 2009;24:25-35.

185. Hedlund E, Pehrsson K, Lange A, Hammar N. Country of birth and survival after first myocardial infarction in Stockholm, Sweden. Eur J Epidemiol. 2008;23:341-7.

186. Matthiessen J, Biltoft-Jensen A, Rasmussen LB, Hels O, Fagt S, Groth MV. Comparison of the danish physical activity questionnaire with a validated position and motion instrument. Eur $\mathbf{J}$ Epidemiol. 2008;23:311-22.

187. Graff-Iversen S, Anderssen SA, Holme IM, Jenum AK, Raastad T. Two short questionnaires on leisure-time physical activity compared with serum lipids, anthropometric measurements and aerobic power in a suburban population from Oslo, Norway. Eur J Epidemiol. 2008;23:167-74.

188. Gemes K, Ahnve S, Janszky I. Inflammation a possible link between economical stress and coronary heart disease. Eur $\mathbf{J}$ Epidemiol. 2008;23:95-103.

189. Zheng H, Orsini N, Amin J, Wolk A, Nguyen VT, Ehrlich F. Quantifying the dose-response of walking in reducing coronary heart disease risk: meta-analysis. Eur J Epidemiol. 2009;24:181-92.

190. Pekkanen J, Sunyer J. Problems in using incidence to analyze risk factors in follow-up studies. Eur J Epidemiol. 2008;23:581-4.

191. Casiglia E, Schiavon L, Tikhonoff V, et al. Electrocardiographic criteria of left ventricular hypertrophy in general population. Eur J Epidemiol. 2008;23:261-71.
192. Stang A. Appropriate epidemiologic methods as a prerequisite for valid study results. Eur J Epidemiol. 2008;23:761-5.

193. Kardys I, Deckers JW, Stricker BH, Vletter WB, Hofman A, Witteman J. Distribution of echocardiographic parameters and their associations with cardiovascular risk factors in the Rotterdam Study. Eur J Epidemiol. 2010;25:481-90.

194. Delaney JA, Scherzer R, Polak J, et al. Effect of inter-reader variability on outcomes in studies using carotid intima media thickness quantified by carotid ultrasonography. Eur J Epidemiol. 2010;25:385-92.

195. Merry AH, Boer JM, Schouten LJ, et al. Validity of coronary heart diseases and heart failure based on hospital discharge and mortality data in the Netherlands using the cardiovascular registry Maastricht cohort study. Eur J Epidemiol. 2009;24:237-47.

196. Thelle DS. The dynamics of cardiovascular epidemiology. Eur J Epidemiol. 2009;24:725-6.

197. Jaddoe VW. Fetal nutritional origins of adult disease: challenges for epidemiological research. Eur J Epidemiol. 2008;23:767-71.

198. Dramé M, Novella JL, Lang PO, et al. Derivation and validation of a mortality-risk index from acohort of frail elderly patients hospitalised in medical wards via emergencies: the SAFES study. Eur J Epidemiol. 2008;23:783-91.

199. Jacobsen R, Oksuzyan A, Engberg H, Jeune B, Vaupel JW, Christensen K. Sex differential in mortality trends of old-aged Danes: a nation wide study of age, period and cohort effects. Eur J Epidemiol. 2008;23:723-30.

200. Wong A. Incident solar radiation and coronary heart disease mortality rates in Europe. Eur J Epidemiol. 2008;23:609-14.

201. Chimonas T, Fanouraki I, Liberopoulos EN, Chimonas E, Elisaf M. Diverging trends in cardiovascular morbidity and mortality in a low risk population. Eur J Epidemiol. 2009;24:415-23.

202. Mayer O Jr, Simon J, Plásková M, Cífková R, Trefil L. Nterminal pro B-type natriuretic peptide as prognostic marker for mortality in coronary patients without clinically manifest heart failure. Eur J Epidemiol. 2009;24:363-8.

203. Lundbye-Christensen S, Dethlefsen C, Gorst-Rasmussen A, et al. Examining secular trends and seasonality in count data using dynamic generalized linear modelling: a new methodological approach illustrated with hospital discharge data on myocardial infarction. Eur J Epidemiol. 2009;24:225-30.

204. Klenk J, Nagel G, Ulmer H, et al. Body mass index and mortality: results of a cohort of 184, 697 adults in Austria. Eur J Epidemiol. 2009;24:83-91.

205. Heidemann C, Boeing H, Pischon T, Nöthlings U, Joost HG, Schulze MB. Association of a diabetes risk score with risk of myocardial infarction, stroke, specific types of cancer, and mortality: a prospective study in the European prospective investigation into cancer and nutrition (EPIC)-potsdam cohort. Eur J Epidemiol. 2009;24:281-8.

206. Gluckman PD, Hanson MA, Bateson P, et al. Towards a new developmental synthesis: adaptive developmental plasticity and human disease. Lancet. 2009;373:1654-7.

207. Stein AD, Wang M, Ramirez-Zea M, et al. Exposure to a nutrition supplementation intervention in early childhood and risk factors for cardiovascular disease in adulthood: evidence from Guatemala. Am J Epidemiol. 2006;164:1160-70.

208. Victora CG, Adair L, Fall C, et al. Maternal and child undernutrition: consequences for adult health and human capital. Lancet. 2008;371:340-57.

209. Masud S, Ye S. Effect of the peroxisome proliferator activated receptor-gamma gene Pro12Ala variant on body mass index: a meta-analysis. J Med Genet. 2003;40:773-80.

210. van Rossum EF, Koper JW, Huizenga NA, et al. A polymorphism in the glucocorticoid receptor gene, which decreases sensitivity to glucocorticoids in vivo, is associated with low insulin and cholesterol levels. Diabetes. 2002;51:3128-34. 
211. Finken MJ, Meulenbelt I, Dekker FW, et al. The $23 \mathrm{~K}$ variant of the R23K polymorphism in the glucocorticoid receptor gene protects against postnatal growth failure and insulin resistance after preterm birth. J Clin Endocrinol Metab. 2007;92:4777-82.

212. van Rossum EF, Koper JW, van den Beld AW, et al. Identification of the BclI polymorphism in the glucocorticoid receptor gene: association with sensitivity to glucocorticoids in vivo and body mass index. Clin Endocrinol. 2003;59:585-92.

213. Rosmond R, Chagnon YC, Holm G, et al. A glucocorticoid receptor gene marker is associated with abdominal obesity, leptin, and dysregulation of the hypothalamic-pituitary-adrenal axis. Obes Res. 2000;8:211-8.

214. Buemann B, Vohl MC, Chagnon M, et al. Abdominal visceral fat is associated with a BclI restriction fragment length polymorphism at the glucocorticoid receptor gene locus. Obes Res. 1997;5:186-92.

215. Huizenga NA, Koper JW, De Lange P, et al. A polymorphism in the glucocorticoid receptor gene may be associated with and increased sensitivity to glucocorticoids in vivo. J Clin Endocrinol Metab. 1998;83:144-51.
216. Watt GC, Harrap SB, Foy CJ, et al. Abnormalities of glucocorticoid metabolism and the renin-angiotensin system: a fourcorners approach to the identification of genetic determinants of blood pressure. J Hypertens. 1992;10:473-82.

217. Di Blasio AM, van Rossum EF, Maestrini S, et al. The relation between two polymorphisms in the glucocorticoid receptor gene and body mass index, blood pressure and cholesterol in obese patients. Clin Endocrinol. 2003;59:68-74.

218. Rosmond R, Bouchard C, Bjorntorp P. Tsp509I polymorphism in exon 2 of the glucocorticoid receptor gene in relation to obesity and cortisol secretion: cohort study. BMJ. 2001;322: 652-3.

219. Lin RC, Wang XL, Morris BJ. Association of coronary artery disease with glucocorticoid receptor N363S variant. Hypertension. 2003;41:404-7.

220. Rosmond R, Chagnon YC, Chagnon M, Perusse L, Bouchard C, Bjorntorp P. A polymorphism of the $5^{\prime}$-flanking region of the glucocorticoid receptor gene locus is associated with basal cortisol secretion in men. Metabolism. 2000;49:1197-9. 